\title{
BİR SOSYAL SORUMLULUK ALANI OLARAK AFET EĞİTIMLERİ
}

DISASTER TRAININGS AS A SOCIAL RESPONSIBILITY FIELD

\author{
Serpil GERDAN ${ }^{1}$
}

\section{ÖZET}

Afetler toplulukları derinden etkileyen ve can ve maddi kayıplara neden olan tehlikelerin olumsuz sonuçlarıdır. Afetlerle baş edebilecek sistemlerin kurulması kadar toplumun afetlere dirençli hale getirilmesi de önemli bir konudur. Bir ülkenin her anlamda sorunlarla baş edebilecek seviyede güçlü hale getirilmesinin anahtarı ise eğitimdir. Eğitim toplulukların bulunduğu çevre ile uyumlu yaşamasını sağlayan önemli bir unsurlardan biridir. Bu çalışmanın amac1, afet eğitimlerinin afete dirençli toplumların oluşturulmasındaki yeri ve önemini vurgulamaktır. $\mathrm{Bu}$ araştırma literatür taraması ve ülkemizdeki mevcut afet eğitim içeriklerinin incelenmesi ile oluşturulmuştur. Araştırmanın sonuçları, afet eğitimlerinin afete dirençli toplum oluşturma sürecindeki önemini açıkça göstermektedir. İçerikleri birbirine göre farklılık gösterse de yapılmış/yapılmakta olan afet eğitimleri bireylerin bilgi ve farkındalık düzeyini belirli ölçüde artırmaktadır. Bireyin eğitim düzeyi de bu farkındalığın olumlu yönde gelişmesinde rol oynamaktadır. Eğitimler gerek bireylerin gerekse toplumun afet anı ve sonrası süreçleri daha kolay geçirmelerine ve normal yaşama dönme çabalarına olumlu katkı sağlamaktadır. Afet eğitimlerin eğitim sistemi içerisine dahil edilmesi afetlerle mücadelede sürdürülebilir ve başarılı yönetim sistemlerinin geliştirilmesinin en önemli unsurudur.

Anahtar Kelimeler: Afet Eğitimi, Sosyal Sorumluluk, Dirençlilik, Hazırlık

\begin{abstract}
Disasters are the negative results of the dangers that affect communities deeply and cause lives and financial losses. Making a resilience community to disasters is an important issue as well as establishing systems that can cope with disasters. Education is the key to making a country more powerful in dealing with problems in every sense. Education is one of the most primary elements that enable people to live in harmony with other people and their environment. The aim of this study is to emphasize the importance of disaster training in making the resilience community. This research was conducted by reviewing the literature and examining the current disaster training contents in our country. The results of the study clearly show the importance of disaster training in the process of creating disaster resilience community. Although their content varies according to each other, trainings of disaster, done, increase the level of knowledge and awareness of individuals to a certain extent. The education level of the individuals plays a role in the development of this awareness in a positive way. These trainings contribute positively to both individuals and the communities to make the process of pre, during and post-disaster easier and return to normal life. Integrate disaster training into the education system is the most important element of the development of sustainable and successful management systems in the fight against disasters.
\end{abstract}

Keywords: Disaster Training, Social Responsibility, Resilience, Preparedness

\footnotetext{
${ }^{1}$ Dr. Öğr. Üyesi, Kocaeli Üniversitesi, İzmit MYO, Türkiye, sgerdan@kocaeli.edu.tr
} 
Türkiye'de afet ve acil durum yönetiminden sorumlu kurum olan Afet ve Acil Durum Yönetimi Başkanlığı (AFAD)'ın Afet Terimler Sözlüğünde yer alan Afetlere Dirençli Toplum kavramı "afet sonrast yaşanan acil durum sürecinin ardından, toplumun olası yeni bir afete karşı daha dirençli kılınması amacıyla yapılan zarar azaltma, hazırlık ve iyileştirme faaliyetleri sonucunda ulaşılan yeterlilik düzeyi. Afetlerin önlenmesi ve zararlarının azaltılması konusunda ĕgitimli ve bilinçli olduğu ve etkin önlemler alabildiği için her tür ve büyüklükteki afetlerden olabildiğince az zarar gören ve hazırlıklı olduğu için de kısa süre içinde ve dışarıdan büyük yardımlar almadan normal yaşam düzenine dönebilen toplulukları ifade eder" olarak tanımlanmaktadır (URL-1, 2018). Tanımdan anlaşılacağı üzere bir toplumun afetlere hazır, baş edebilir ve dirençli olmasının anahtarı eğitimdir. Eğitim Forrester vd diğ. (2016) tarafından bireylerin bilgi ve beceri düzeylerini artıran, algılarını değiştiren bir kavram olarak tanımlanmaktadır. Eğitim, bireylerin farkındalık düzeyini olumlu yönde geliştiren, düşünen, yetenekli bireyler olmalarını sağlayan en temel ihtiyaçlardan biridir. Eğitim ile bilgiye daha kolay ulaşan, ulaştığı bilgiyi yetenekleri ile birlikte kullanabilen ve daha az hata ile karar verebilen bireyler yetişir (Mizrak, 2018). Liu vd. (2017)'ye göre dirençlilik çekirdek direnç, içsel direnç ve dışsal dirençten oluşan üç katmanlı bir yapıya sahiptir. Zaman içerisinde durağan kalan ve psikolojik ve fiziksel özelliklere bağlı olan çekirdek direnç, bireyin bireysel özellikleri ile ailevi özelliklerini ve eğitim durumunu belirleyen içsel direnç ile sarmalanmıştır. Dışsal direnç ise çevresel coğrafi özellikler gibi dışsal etmenlere bağlı gelişen direnci temsil etmektedir (Liu, 2017; Varol ve Kırıkkaya, 2018). 2015-2030 yıllarını kapsayan Sendai Bildirgesinde eğitimdeki eksiklerin dirençlilik çerçevesinde incelenmesini ve eğitimin tüm seviyelerinde etkili bir ş̧ekilde uygulanmasını sağlayabilecek çözüm önerileri sunmaktadır. Eğitim ve dirençlilik arasındaki ilişkiye bakıldığında eğitimin bireyin veya toplumun zarar görebilirliğini azaltan temel faktörlerden biri olduğu açıkça görülmektedir. İster doğrudan ister dolaylı olsun risk algısını geliştirecek olan eğitim bireyi bu risk/riskleri azaltacak çözümleri üretmeye teşvik edecektir. Bireyler bilmedikleri bir şeyden korkmak yerine nasıl oluştuğunu ve ne tür önlemlerle baş edebileceklerini bildikleri tehlikelere karşı kırılgan olmaktan dirençli olmaya geçeceklerdir. Bireydeki bu değişim ve gelişim topluma yansıdığında ise istenen bütünleşik afet yönetim sistemi hayata geçmiş olacaktır. Bütünleşik afet yönetim sistemi; alınan önlemlerle olayların önlenemediği durumlarda toplumun her kesimi ile insan malı ile milli servetlerin afetlerin yıkıcı etkilerinden korunması için hazırlıklı olma felsefesini benimser. Hazırlıklı olmak aynı zamanda, afet halinde yetki ve sorumlulukların belirlenmesi ve destek kaynaklarının düzenlenmesi gibi konularda da hazırlıklı olmayı içerir. Hazırlıklı olmak tüm kurum ve kuruluşlar ile bireylerin güç ve kaynaklarını afetlerin olumsuz etkilerinden korunmak için kullanacak altyapıyı sağlamak demektir. Gerekli ekipman ve donanımların bakımı, tahmin ve erken uyarı sistemlerinin kurulumu ve kullanımı, görevli personelin/personellerin eğitimi ve diğer aktivitelere hazırlık yine bu aşamada yürütülen faaliyetlerdir (Kadığlu, 2008; Özmen ve diğ., 2017; Şahin 2016).

Afetler oluş şekilleri, etkileri ve sebep oldukları olumsuz sonuçlara bağlı olarak bireyleri ve bağlı oldukları toplumları olayın sonrasında kısa ve uzun dönemde farklı şekillerde etkileme potansiyeline sahiptirler (Gil-Rivas ve Kilmer, 2016). Normal işleyen sistemler afetler sonrası kilitlenmekte ve mevcut hizmetler yürütülememektedir. Afetler sonrası yerel hizmetler ile eğitim faaliyetlerinin yürütülememesi bu duruma örnek olarak verilebilir. 
20 y1ldan fazla süredir, yılda ortalama 340 felaket meydana gelmektedir. Meydana gelen bu felaketler nedeniyle 200 milyona yakın insan etkilenmekte ve ortalama 67.500 kişi yaşamını yitirmektedir. Toplulukları darmadağın eden doğal felaketlerle ilgili acı gerçeklerden bir tanesi ülkelerin ekonomik gelişmişliğinin, afet kayıpları üzerinde etkili olmasıdır. Yüksek gelirli ülkeler \%56 oranında doğal afetlere maruz kalmakta olup vermiş oldukları kayıp \%36 oranında iken, düşük ve orta gelirli ülkeler \%44 oranın doğal felaketlere maruz kalmakta ve vermiş oldukları kayıp oranı \%68 olarak görünmektedir. $\mathrm{Bu}$ durum ekonomik gelişmişliğin insan yaşamına ne denli olumsuz etkilediğini göstermektedir. Ekonomik sistemin zayıf, kırılgan olduğu sistemlerde buna bağlı olarak eğitim gibi toplumu doğrudan etkileyen sistemler de maalesef zayıf olmaktadır (URL-2). 2016 yılında dünyada meydana gelen doğa kaynaklı afetlerde 7628 kişi hayatını kaybetmiş ve 411 milyon insan etkilenmiştir. 2016 yılındaki doğa kaynaklı afetlerin \%6 sı ile can kayıplarının \%16 sına yaşanan depremler sebep olmuştur. Son 10 yıllık doğa kaynaklı afet olayları ortalamalarında en fazla artış 2016 yılında gerçekleşmiştir. Türkiye'de 2016 yılında can ve mal kaybına yol açan 323 doğa kaynaklı afet gerçekleşmiştir. Sel ve su baskınları tüm bu afetlerin \%34 ünü oluşturmuştur. Dünya Risk Raporlarında Türkiye en yüksek riskli ülkeler arasında 12. sirada yer almaktadır. "Risk Düzeyi ve Eğilimi"" açısından bakıldığında da Türkiye "riski en yüksek ve artış eğilimli” 10 ülke içinde yer almaktadır (Ersoy ve diğ., 2017).

\section{Afet Farkındalı̆̆ı}

Toplumun afetlere hazır, daha az zarar görebilir hale getirilmesinde farkındalığın artırılması önemli bir role sahiptir. Farkındalık öğrenilebilen bir beceridir. Afet farkındalığının geliştirmenin yollarından birisi yaşanan afet tecrübesi iken bir diğeri eğitimdir. Afetlerle baş edebilmek tehlikenin nereden, nasıl geleceğini doğru tespit edebilmekten geçer. Olası afetlerin olumsuz etkilerinden ve kayıplardan sürekli bahsetmek toplumu karamsarlığa ve ümitsizliğe sürükler. Oysa risklerin bilinmesi algılama, farkındalık ve mücadele becerisini geliştirir (Kundak, 2018). Tehlikenin kendisinin doğal bir süreç olarak anlaşılması olay sonrası süreçlere ağırlık verilmesine yol açarken, tehlike ile olası risklerinin algılanması fikri afet öncesi hazırlık ve sakınım süreçlerine ağırlık kazandırır (Aydıner, 2014).

Türkiye'deki afet yönetimi 1999 Marmara depremleri öncesi afet sonrası müdahale faaliyetlerine ağırlık vermekteydi. 1999 sonrası yeni kurumsal yapılanmalar ile afet öncesi hazırlık ve farkındalık çalışmalarına ağırlık verilmeye başlandı. Bilindiği üzere afete hazırlıklı olmak, afet eğilimi olan bölge ve ülkeler için son derece gerekli ve önemli bir konudur. Doğal veya teknolojik kaynaklı tehlikelere karşı hazırlık ve erken uyarı sistemleri gibi gelişen teknolojilerin kullanımı afete maruz toplulukların yaşam ve geçim kaynağı üzerindeki olumsuz etkilerini azaltmaya yardımcı olur.

Afet bilinci, toplulukları çevrelerindeki tehlikelerden haberdar etmek ve daha da önemlisi daha iyi hazırlanmaları için onları bilgilendirme yaklaşımıdır (DA, 2018, DDA, 2018). Şekil 1'de tehlike algısı ile farkındalık arasındaki ilişki şematik olarak gösterilmektedir (Kundak, 2018). Her ne kadar 5902 sayılı kanun ile kurulan Afet ve Acil Durum Yönetimi Başkanlığı (AFAD) merkezi otorite olarak gerek politika gerek bütçeyi organize etme anlamında önemli role sahip olsa da afet konusunda öncelikle yerelde durumun anlaşılması ve gerekli tedbirlerin alınması, toplumdaki farkındalığın yerelde artırılması çok önemlidir. Yerel ölçekte dirençli şehirlerin oluşturulmasında 3 temel kural; 


\section{IJMA}

1- Riski anlamak ve bilmek,

2- Yerel yönetimlerin yatırım ve planlamalarını kendi riskleri doğrultusunda planlamas1,

3- Güvenli bina ve tesislerin inşasıdır (AFAD, 2018).

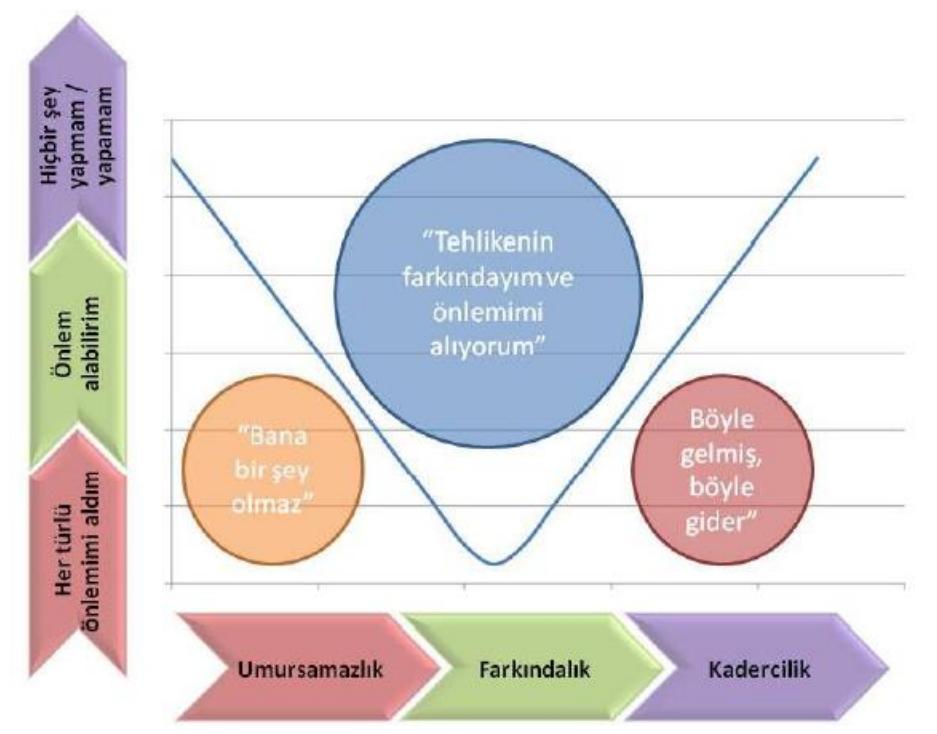

Şekil 1. Tehlike-farkındalık ilişkisinin önemi (Kundak, 2018)

Kundak, (2018)'e göre, farkındalık yaklaşımını umursamaz ve kaderci yaklaşımdan ayıran en büyük özellik, bireyin veya topluluğun tehlike kaynağı ve olabilecekler hakkında bir fikir sahibi olmasıdır. Bu farkındalık bireyde veya toplumda kaygı teslimiyet duygusundan çok imkanlar doğrultusunda önlem alma eğilimini tetikler (Kundak, 2018).

\section{Afet Eğitimlerinin Önemi ve Faydaları}

Ülkemizde gerek 1999 depremlerinin hemen sonrasında gerekse geçen yıllar içerisinde verilen afet eğitimlerine bakıldığında çabalar ne kadar iyi niyetli olursa olsun eğitimler kısa, sürekliliği olmayan projeler olarak kalmıştır. Yerelde belediyeler ve ilgili kurumların işbirliği ile yürütülen projeler ve hazırlanan eğitim içerikleri kısa vadede belirli bir yol kat edebilmiş ancak eğitim kazanımları ve bireyde davranış değişikliğine yol açıp açamadığı konusunda somut sonuçlar elde edilememiştir. Bu durumun en önemli nedenleri ilgili kurumların yerelde güç ve imkanlarının kısıtlı olması ve bu alanda çalışan yetkin insan gücünün sınırlı olması gösterilebilir. Afet ve Acil Durum Yönetim Başkanlığının (AFAD) bu alandaki sorunların farkında olması ve Milli Eğitim Bakanlığı ve Japonya Uluslararası İşbirliği Ajansı (JICA) ile başlattığı projeler de ne yazık ki yaygınlaştırma aşamasında sorunlar yaşamıştır. Elbette ki bu sürecin Milli Eğitim Bakanlığı ile birlikte ve eşgüdüm içinde kurgulanması en istenen durumdur. Bununla birlikte afet eğitimi alanında mutlaka profesyonel eğitimcilerin de yetişmesi şarttır.

Afet eğitiminde toplumun gereksinmelerini karşılayacak bir planlama-uygulamadeğerlendirme süreci geliştirilmeli ve alan uzmanları, yöneticiler ile karar vericilerin afet yönetimi ile ilgili eğitilmeleri gerekmektedir (Akın, 2018). AFAD'ın 2014 yılında 4038 hane (2.816's1 kent ve 1.380'i kır) üzerinde gerçekleştirdiği “Türkiye Afet 
Farkındalı̆̆1 ve Afetlere Hazırlı Araştırması" sonuçları afet farkındalı̆̆ının artırılmasına yönelik yapılacak çalışmaların, toplumun özellikle daha az eğitim almış bireylerine yönelik olarak yoğunlaşması gerektiğini göstermektedir. Katılımcıların \%40.7 (f=1.643)'si yaşadığı bölgedeki muhtemel afetler konusunda bilgilendirilmesi gerektiğini, \%26.8 (f=1.083)'i afetlerle ilgili etkinliklerin yapılması gerektiğini düşünmektedir. Bu sonuçlar, ülkemizde yoğun olarak maruz kaldığımız afetlerle ilgili eğitimlerin özellikle bölgesel riskleri dikkate alarak çeşitlendirilmesi gerektiğini göstermektedir. Yine aynı çalışmada, afetlere yönelik eğitim almak isteyenlerin \%74'ü ilk yardım eğitimi almak istemektedir. Afetlere müdahale eğitimi almak isteyenlerin oranı ise $\% 35$ iken, katılımcıların $\% 34$ 'ü afetlerde davranış biçimlerine yönelik eğitim almak istemektedir (AFAD, 2014). Buraya kadar değindiğimiz üzere, afet eğitimlerinin amacı, birey ve toplumun afetler karşısında dirençliliğini artırmak ve onlara afetlere nasıl hazırlıklı olacakları konusunda yardımcı olarak müdahale ve afet öncesi normal yaşama dönme çabalarının etkinliğini artırmaktır. Afet eğitimi demek aslında afet anında insanların güvenliğinin artırılması demektir (Mızrak, 2018). Bu nedenle hazırlanacak afet eğitim içeriklerinin afet öncesi, sırası ve sonrası gerekli olan en doğru bilgiyi, ilgili tüm birey ve kurumlara en doğru aktaracak şekilde olması gerekir.

Zarar azaltma, hazırlık, müdahale ve iyileştirme aşamalarından oluşan afet yönetim sistemi zarar azaltma ve hazırlık ile afet öncesi risklerin yönetildiği, müdahale ve iyileştirme ile olay sonrası krizin yönetildiği bütüncül bir sistemdir. Aynı zamanda yaşanan her olay/afet sonrası edinilen tecrübelerle bir sonraki olay veya tehlikenin daha sorunsuz atlatılmasını sağlayacak firsatları da içinde barındıran döngüsel bir sistemdir. Afete hazırlık eğitimleri afet ve acil durum planlamasının bir parçasıdır ve risk yönetiminin hazırlık evresinde sisteme katkı sağlar. Topluma yönelik gerçekleştirilecek afet eğitimlerinin ezberden çok beceriyi geliştirmeye yönelik olmalıdır. Eğitimlerle gerçekleştirilecek uygulamaların uluslararası standartta ve profesyonel/alan uzmanı kişiler tarafından verilmesi gerekir. Afet eğitimleri, afet konusunda yönetici, karar verici seviyede çalışanlar için "Afet Yönetim Eğitimi”, bireyler için ise "Temel Afet Bilinci" veya "Afet Bilinci" olarak verilmelidir. Bireylere/halka yönelik verilecek eğitimlerin afetlerde doğru davranış biçimleri, önleme ve zarar azaltma gibi belli başlı temel bilgileri içermesi ve tatbikatlarla desteklenmesi gerekir (Kadıoğlu, 2005).

\section{Türkiye'de Afet Eğitimleri}

Dünyada ve ülkemizde afet eğitimleri "acil durum eğitimi", "kriz eğitim", "afet bilinci eğitimi” gibi farklı isimler altında verilmektedir. Ancak günümüzde artık afet zararlarının azaltılması çalışmaları ve eğitimleri küresel anlamda "Afetlerin Azaltılmasında Uluslararası Stratejilerin (UN/ISDR)” geliştirilmesi çerçevesinde şekillenmektedir. $\mathrm{Bu}$ durum afet öncesi çalışmaların hız kazanması anlamına gelmektedir. Bu çalışmalar 2005 yılında gündeme gelen Hyogo Çerçeve Eylem Planı (Hyogo Framework for Action) 1şı̆̆ı altında devam etmektedir. Hyogo planının beş önceliğinin üçüncüsü "bilginin kullanımı ve güvenlik kültürünün yerleşmesi için eğitime önem verilmesi" dir. 1987 yılında imzalanan Avrupa ve Akdeniz Büyük Afetler Anlaşması (EUR-OPA) anlaşması gereğince, her ülkede kendileri için belirlenen görevleri yerine getirmek üzere ülkemizde Avrupa Doğal Afetler Eğitim Merkezi (AFEM) kurulmuştur. Günümüzde AFEM faaliyetleri AFAD Planlama ve Risk Azaltma Daire Başkanlığınca yürütülmektedir (URL-3). AFEM'in eğitim hedef kitlesi, uzmanlar, idareciler, eğiticiler, karar vericiler, ilköğretim okulları ve halktır. Halkın kademeli olarak afet konusunda eğitilerek afet bilincinin oluşturulması ve afete hazır bir 
toplum oluşturulması Avrupa Doğal Afetler Eğitim Merkezi (AFEM) in ana amacıdır (Varol, 2007). Diğer taraftan, 7126 sayll Sivil Savunma Kanunun 23 ve 32'nci maddeleri gereğince, "sivil savunma hizmetlerinin gerektirdiği eğitim ve öğretimleri yapmak üzere" İçişleri Bakanlığ Sivil Savunma Genel Müdürlüğüne bağlı olarak 17 Kasım 1960 tarihinde kurulan Afet ve Acil Durum Eğitim Merkezi; "Sivil Savunma Koleji", 5902 sayılı "Afet ve Acil Durum Yönetimi Başkanlığının Teşkilat ve Görevleri Hakkında Kanunu"nun yürürlüğe girmesiyle Afet ve Acil Durum Eğitim Merkezi (AFADEM) adını almıştır. AFADEM, AFAD Planlama ve Zarar Azaltma Dairesi Başkanlığı bünyesinde afet, acil durum ve sivil savunma hizmetlerine ilişkin eğitim faaliyetlerini sürdürmektedir.

1999 depremleri sonrası çeşitli kurum ve kuruluşlar tarafından gerçekleştirilen afet eğitimlerinden bazıları aşağıda verilmiştir.

$\checkmark$ AFAD Afete Hazır Türkiye Projesi

- Afete Hazır Aile

- Afete Hazır Okul

- Afete Hazır İşyeri

- Afete Hazır Gençler

$\checkmark$ Boğaziçi Üniversitesi, Kandilli Rasathanesi ve Deprem Araştırma Enstitüsü, Afete Hazırlık Eğitim Birimi (AHEB) Eğitimleri:

- ABCD Temel Afet Bilinci,

- Depreme Karşı Yapısal Bilinç (DKYB),

○ Toplum Afet Gönüllüleri,

○ Yapısal Olmayan Tehlikelerin Azaltılması (YOTA)

$\checkmark$ JICA, Milli Eğitim bakanlığı (MEB) Okul Tabanlı Afet Eğitimi

$\checkmark$ AFAD- JICA Etkin Afet Risk Yönetimi için Kapasite Geliştirme Projesi

$\checkmark$ Türk İşbirliği ve Koordinasyon Ajansı Başkanlığı (TİKA), Japonya Uluslararası İşbirliği Ajansı (JICA) ve Orta Doğu Teknik Üniversitesinin (ODTÜ), işbirliğinde "Afet Risklerinin Yönetimi ve Afete Karşı Dirençli Toplumların Oluşturulması" konulu eğitim programı

$\checkmark$ İstanbul Büyükşehir Belediyesi İnsan Kaynakları ve Eğitim Daire Başkanlığı Eğitim Müdürlüğü, İl Milli Eğitim Müdürlüğü ve Afet Koordinasyon Merkezi (AKOM) işbirliğinde "Afetlerden Korunma Eğitimi”"

$\checkmark$ Yerel düzeyde belediyelerin gerçekleştirdikleri halka yönelik afet eğitimlerinden bazıları aşağıda listelenmiştir.

○ İzmir Büyükşehir Belediyesi, "Yangın ve Doğal Afet Eğitimi”"

○ Buca Belediyesi, “Uygulamalı Afet Eğitimi”, (URL-4, 2018)

○ Karşıyaka Belediyesi, “Doğal Afet Öncesi Hazırlık Eğitimi”, (URL-5, 2018)

○ Kadıköy Belediyesi, “Afet Eğitim Bilinçlendirme Çalışmaları” (URL-6, 2018),

- Kocaeli Büyükşehir Belediyesi, Kocaeli İl AFAD, Kocaeli Üniversitesi, "Kocaeli Mahalle Halkı Afete Hazırlık Eğitimi”, (URL-7, 2018) 
○ Alanya Belediyesi "Yangın ve Afet Eğitimi (URL-8, 2018)

○ Bolu Belediyesi “Öğrencelere Afet Eğitimi” (URL-9, 2018)

○ Narlıdere Belediyesi “Çocuklara Afet Eğitimi” (URl-10, 2018)

○ Osmangazi Belediyesi “Öğrencilere Simülasyonlu Afet Eğitimi” (URL-11, 2018)

○ Küçükçekmece Belediyesi “Engellilere Yönelik Afet Eğitimi” (URL-12, 2018)

○ Kağıthane Belediyesi “Afet Eğitimi” (URL-13, 2018)

○ Çekmeköy Belediyesi “Öğrencilere Afet Eğitimi” (URL-14, 2018)

○ Fatih Belediyesi "Sivil Savunma ve Temel Afet Bilinci Eğitimi" (URL-15, 2018)

○ Bursa Büyükşehir Belediyesi “Uygulamalı Afet Eğitimi” (URL-16, 2018)

○ Adana Büyükşehir Belediyesi, "Simülasyon Tırı ile Afet Eğitimi” (URL-17, 2018)

\section{SONUÇ ve ÖNERILER}

Gerek doğal olaylar gerekse teknoloji veya insan kaynaklı afetler her geçen gün daha çok can ve maddi kayıplara sebep olmaktadır (Yavaş, 2005). Dünyada hiçbir ülkenin afetler açısından tam güvenli olduğunu söylemek maalesef mümkün değildir. Afetlerin etkilerinin sınırlandırılmasına yönelik kapasite ve yatırım eksiklerinin yeterince olmayışı, nüfusun kontrolsüz ve hızla artışı, mühendislik hizmeti almadan inşa edilmiş binalar, yetersiz altyapı ve çarpık kentleşme gibi sebepler toplumun kırılganlığı artmaktadır (Gökçe ve diğ., 2008). Oysa afetleri mümkünse önlemek, mümkün olmadığı durumlarda daha az zararla atlatmak bir başka deyişler olumsuz etkilerini hafifletmek toplumun ve sistemlerin dirençli olması ile mümkündür.

Her alanda zorunlu ve önemli olan eğitim, özellikle afetler söz konusu olduğunda daha da önem kazanmaktadır. Bilginin yönetilebilmesi ve eğitim, afete maruz bölgelerdeki toplulukların riskleri daha iyi anlamalarını sağlayan ve baş edebilme becerilerini geliştiren iki kavramdır. Afet yönetiminin her aşaması planlama ve buna bağlı olarak eğitim faaliyetlerini içerisinde barındırır. İçerikleri birbirinden farklı olsa da eğitimler toplumun yapı taşı olan bireylerin yaşam alanları içerisindeki tehlike ve risklerin farkına varmalarını ve korkmak yerine önlem alma dürtülerinin gelişmesini sağlamaktadır. Evinde alacağı basit önlemlerle yaralanma hatta ölüm riskini azaltabileceğinin farkına varan bir birey afetlerle mücadelede sorunun değil çözümün bir parçası olduğunun da farkında varacaktır. Bu farkındalık bireyden topluma yaygınlaştıkça dirençli bir toplum olarak afetlerin olası zararları da azalmış olacaktır. Afet eğitimi almış bir birey, afet öncesi önlemlerini almış olmanın yanı sıra afet anında nasıl davranacağını ve afet sonrasında hızla nasıl toparlanacağını da bilen bireydir. Yapılan araştırmalar aile ve özellikle çocuklara verilen ve bireyin etkin katılımının sağlandığı afet eğitimlerinin daha yararlı olduğunu göstermektedir. Afetlerle ilgili kavramlar formal eğitim sistemi içerisinde ilköğretim 4. Sınıfta "Yaşadığımız Yer", 5. Sınıfta "Bölgemizi Tanıyalım" ve 6. Sınıfta "Ülkemiz ve Dünya" ünitelerinde, orta öğretimde ise "Çevre ve Toplum" ünitesinde verilmektedir (Karakuş ve Önger, 2017). Bu eğitimlerin sosyal sorumluluk kapsamında ilgili kurumların verdiği afet eğitimleri ile pekiştirilmesi çocukların/gençlerin afetler ve çevrelerindeki tehlikeler hakkındaki bilgi düzeylerini 


\section{$\mathrm{MMA}=$

artıracak ve toplumun uzun dönem dirençli olmasını sağlayacaktır. Başarılı bir afete müdahale sürecinde afet sonrası altın saatler olarak bilinen ilk 72 saatte yetkililer/profesyoneller afetzedelere yönelik faaliyetleri yürütürken afetten sağ olarak kurtulan bireylerin kendi ihtiyaçlarını karşılayabilecek kapasiteye sahip olması beklenir. $\mathrm{Bu}$ beklentinin gerçekleşmesini sağlayacak anahtar; toplumun afetlerle ilgili bilgi ve beceri düzeyinin yüksek tutulmasıdır. Afet eğitim düzeyi yetersiz olan bireyler afetlere etkili hazırlanamayacakları gibi afet sırası ve sonrasında karar vericilere yük olacak ve toplumun uyumunu bozacaklardır. Toplumun afet bilgi düzeyi ile afet dirençliliği arasındaki doğru orantı düşünüldüğünde bireyden topluma her kesimin, devletlerin ve hatta dünyamızın geleceği için afet eğitimleri kaçınılmaz bir ihtiyaçtır. Bu ihtiyaç yüksek kalitede, etkin bir eğitim içeriği ile sağlanabilir. Eğitim içerikleri, bölgesel, ulusal düzeyde ihtiyaçlara göre belirlenmeli, alanında uzman kurum ve eğitmenlerle, eğitimin her kademesine yayılarak belirli standartta verilmeli ve süreklilik arz etmelidir. Afet eğitimlerinin kalitesinin uzman ellerde mevcut eğitim sistemi ile desteklendiğinde daha anlamlı olacağı unutulmamalıdır. Disiplinler arası bir yaklaşım gerektiren afetlerle ilgili eğitimlerin ilk, orta ve yüksek öğrenim seviyelerinde alan bilgisi ile desteklenerek sisteme dahil edilmesi ve gerek yerel yönetimler gerekse ilgili kurumlarla işbirliği ile desteklenmesi afetlere karşı daha güvenli, daha dirençli toplulukların, kentlerin ve ulusların inşa edilmesi için bir zorunluluktur.

\section{KAYNAKÇA}

AFAD, 2014, Türkiye Afet Farkındalığı ve Afetlere Hazırlık Araştırması,

AFAD, 2018, Afete Dirençli Toplum Oluşturmada Yerel Yönetimlerin Rolü Çalıştayı,https://www.afad.gov.tr/tr/27735/Afete-Direncli-Toplum-OlusturmadaYerel-Yonetimlerin-Rolu-Calistayi-Basladi

Akın, D., (2007), Eğitim Ne Kadar Önemli?, TMMO Afet Sempozyumu, http://www.imo.org.tr/resimler/ekutuphane/pdf/3888.pdf

Aydıner, T., 2014, Doğal Afet Yönetişimi: Türkiye'de Doğal Afet Yönetimi Uygulamalarının Tarihsel Bağlamda Değerlendirilmesi, Yüksek Lisans Tezi, SBE, Pamukkale Üniversitesi,

DA, 2018, Disaster Awarenes, http://pngndc.gov.pg/?page_id=53

DAA, 2018, Raising Disaster About Awareness, http://pprdeast2.eu/en/povyshenieosvedomlennosti/

Ersoy, Ş., Nurlu, M., Gökçe, O., Özmen, B., (2017), 2016 Y1lında Dünyada ve Türkiye'de Meydana Gelen Doğa Kaynaklı Afet Kayıplarının İstatistiksel Değerlendirmesi

Forrester, I. T., Mayaka, P., Brown-Fraser, S., Dawkins, N., Rowel, R., \& Sitther, V. (2016). Earthquake disaster resilience: A framework for sustainable gardening in Haiti's vulnerable population. Journal of Hunger \& Environmental Nutrition, 12(1), 136-149. DOI:10.1080/19320248.2016.1157549.

Gil-Rivas, V., \& Kilmer, R. P. (2016). Building community capacity and fostering disaster resilience. Journal of Clinical Psychology, 72(12), 1318-1332. DOI:10.1002/jclp.22281. 
Gökçe, O., Özden, Ş., Demir, A., (2008), Türkiye'de Afetlerin Mekansal ve İstatistiksel Dağılımı, Afet Bilgileri Envanteri, T.C. Bayındırlık ve İskan Bakanlı̆̆l, Afet İsleri Genel Müdürlüğü, Afet Etüt ve Hasar Daire Başkanlığı Yayınları

Kadıoğlu, M., (2005), Afete Hazırlık ve Afet Bilinci Eğitiminde Verilen Mesajların Standardizasyonu, Deprem Sempozyumum Kocaeli 2005

Kadıoğlu, M., (2008), Modern, Bütünleşik Afet Yönetimin Temel İlkeleri; Kadıoğlu, M. ve Özdamar, E., (editörler), Afet Zararlarını Azaltmanın Temel İlkeleri, JICA Türkiye Ofisi Yayınları No: 2, Ankara. s. 1-34

Karakuş, U., Önger, S., (2017), 8. Sınıf Öğrencilerinin Doğal Afet ve Afet Eğitimi Kavramını Anlama Düzeyleri, Journal of History Culture and Art Research, Vol.6, No.6

Kundak, S. 2018, Şehirler, Afetler ve İnsan, http://dosya.toprakisveren.org.tr/makale/2011-92-sedakundak.pdf

Liu, J.W.W., Reed, M., (2017). Advancing resilience: An integrative, multi-system model of resilience. Girard Personality and Individual Differences 111, 111-118.

Mizrak, S., (2018, Eğitim, Afet Eğitimi ve Afete Dirençli Toplum, MSKU Ĕgitim Fakültesi Dergisi, Cilt-Volume 5, Say1- Number 1, 56-67.

Özmen, B., Özden, A.T., Gerdan, S., Tezgider, G., Gökçe, O., 2017, Afet Yönetimi-I, Anadolu Üniversitesi, AÖF Yayınları, Yayın No: 236, ISBN: 978-975-06-2139-0

Şahin, G., (2016), Yerel Yönetimlerde Afetlere Hazırlık ve Zarar Azaltma Sorumlulukları: İzmir Büyükşehir Belediyesi Örneği, KAYSEM 10- Kamu Yönetimi Sетровуити, 935-966

Varol, N., (2007), Doğal ve Teknolojik Afetler Konusunda Toplumun Bilinçlendirilmesi Ve "AFEM'in Rolü, TMMOB Afet Sempozyumu, http://www.imo.org.tr/resimler/ekutuphane/pdf/3895.pdf

Varol, N., Kırıkkaya, E.B., (2017), Afetler Karşısında Toplum Dirençliliği, Journal of Resilience, Cilt 1, Say1 1, https://dx.doi.org/10.32569/resilience.344784.

Yavaş, H., (2005), Türkiye'de Doğal Afetlerin Merkez-Yerel İlişkiler Açısından Yönetim Sorunları, Dokuz Eylül Üniversitesi, Sosyal Bilimler Enstitüsü Dergisi, Cil:7 Sayı: 3,

URL-1 https://www.afad.gov.tr/tr/23792/Aciklamali-Afet-Yonetimi-TerimleriSozlugu?kelime=afetlere+diren\%C3\%A7li+toplum

URL-2 https://insamer.com/tr/dunyanin-afet-tablosu-ve-cozum-onerileri_380.html

URL-3 Avrupa Doğal Afetler Eğitim Merkezi (AFEM), (2018) https://www.afad.gov.tr/tr/26593/Avrupa-Dogal-Afetler-Egitim-Merkezi-AFEM

URL-4 http://www.buca.bel.tr/Haberler/1507/buca-belediyesi--nden-uygulamali-afetegitimi.html

URL-5 http://www.karsiyaka.bel.tr/tr/faaliyetlerimiz/engelsiz-yatirimlar/afet-egitimi

URL-6 http://www.kadikoy.bel.tr/Haberler/kadikoy-belediyesinden-afet-egitimbilinclendirme-calismalari

URL-7 https://kocaeli.afad.gov.tr/tr/17767/Mahalle-Halki-Afetlere-Hazirlik-Projesi 
IJMA $=m_{1=0}$

URL-8https://www.alanya.bel.tr/Haber/11982/ALANYA-BELEDIYESI-

CALISANLARINA-YANGIN-VE-AFET-EGITIMI

URL-9 https://www.bolu.bel.tr/haberler/ogrencilere-afet-egitimi/

URL-10 http://www.narlidere-bld.gov.tr/HaberDetay/2105/narlidere-nin-cocuklarinaafet-egitimi

URL-11 http://www.osmangazi.bel.tr/tr/haber/ogrencilere-simulasyonlu-afet-egitimi

URL-12http://kucukcekmece.istanbul/icerikler/haberler/turkiye-de-ilk-kez-engellilereyonelik-afet-egitimi/156

URL-13 http://www.kagithane.istanbul/guncel/haber_detail/KAGITHANELIKADINLAR-AFETLERE-KARSI-DAHA-DA-GUCLU/441/3169/0

URL-14 https://cekmekoy.bel.tr/tr/cekut-tan-ogrenc-lere-afet-eg-t-m-

URL-15 http://www.fatih.bel.tr/sivilsavunma/

URL-16 https://www.bursa.bel.tr/uygulamali-afet-egitimi/haber/15897

URL-17 http://www.adana.bel.tr/simulasyon-tiri-ile-afet-egitimi/ 